\title{
The Federal Budget and the Economy
}

\author{
by DENIS S. KARNOSKY
}

\begin{abstract}
T. he typical problems involved in formulating a budget for the Federal Government are compounded this year by concern about persistent inflation in the face of rising unemployment and falling production. The Administration considers fiscal restraint essential in order to continue the fight against inflation and has proposed that the budget for the fiscal year ending next June be approximately balanced. Congress has acted on only a small portion of the proposed budget program, but many analysts believe that a substantial budget deficit will develop.

The prospect of a large Federal deficit in fiscal 1971 stems from three factors. There is a possibility that Congress will enact legislation which will result in Government spending in excess of that requested by the Administration. Second, there is some doubt as to whether several proposed tax programs will be adopted. The third factor is the pattem of economic activity in the coming year. Moderation in growth of total spending since late 1969 caused tax revenue to fall significantly short of projections in fiscal 1970 and, similarly, revenue growth in fiscal 1971 is expected to be moderate.
\end{abstract}

\section{The Proposed Budget in Perspective}

The actual Federal budget in fiscal 1971 will not be known for about a year. At the moment the main clue to current and forthcoming fiscal action is the budget report submitted by the President to Con* gress in February and revised on May 19. Although the actual budget is often quite different from the proposed budget, that report can be used as a point of departure, in that it indicates the thrust of fiscal actions advocated by the Administration.

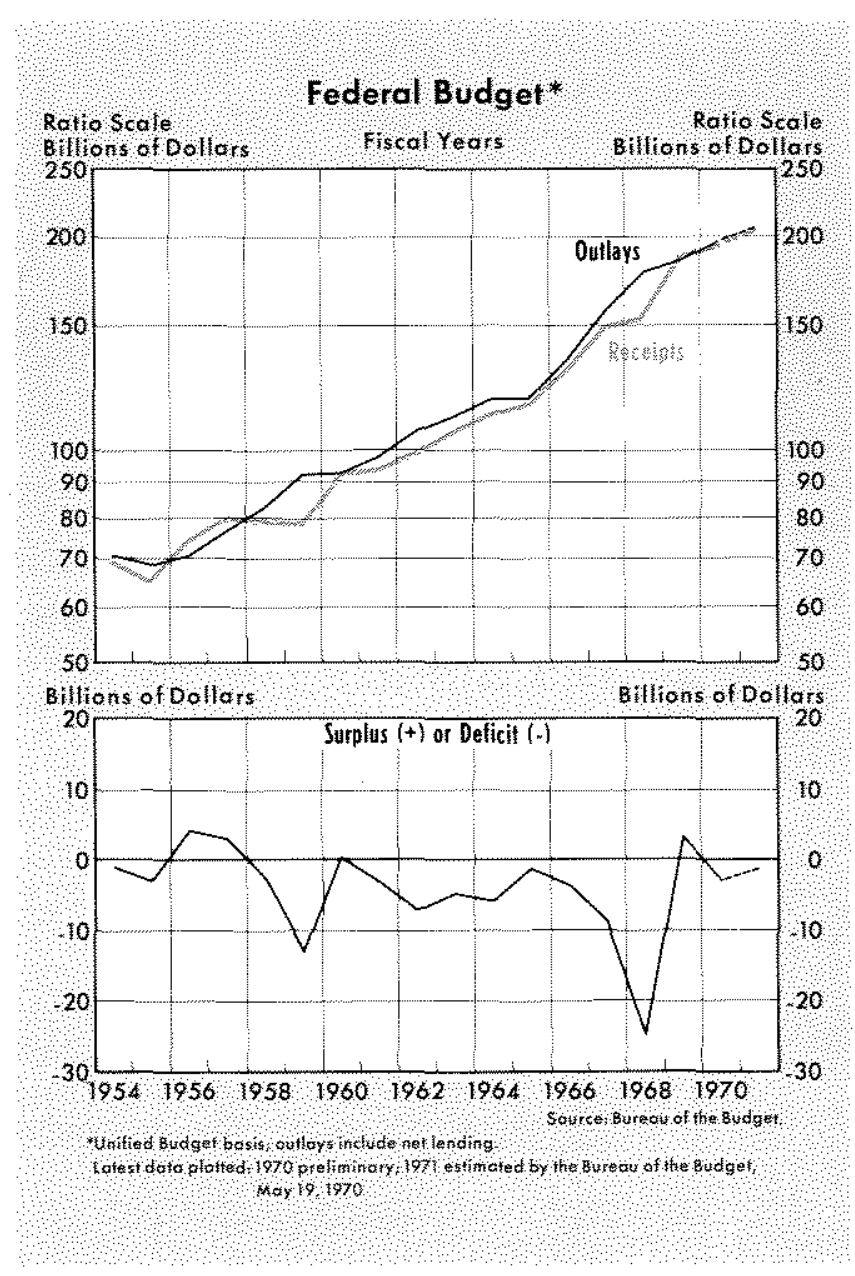

\section{Outhers}

The President's proposed budget for fiscal 1971 calls for total outlays of $\$ 205.6$ billion, an increase of 4.5 per cent from fiscal 1970 . This plan would con- 


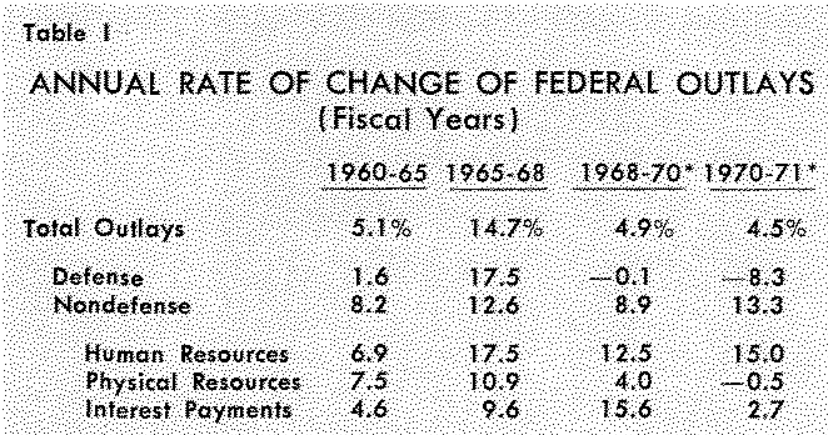

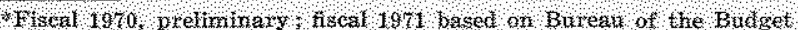
data, 1 hy 19,1970

tinue the pattern of relatively moderate growth in spending which has been followed since enactment of the Revenue and Expenditure Control Act in mid1968. Total outlays increased at about a 15 per cent average rate during the three-year period from fiscal 1965 to fiscal 1968, but grew at a reduced 5 per cent rate in the last two budget years.

A reduction in defense spending is planned for fiscal 1971, and outlays for nondefense programs are projected to continue increasing rapidly, Defense spending is projected to decline by $\$ 6.7$ billion in this fiscal year, to $\$ 73.6$ billion, only slightly higher than in fiscal 1967. Other spending is planned to increase $\$ 15.5$ billion, a 13 per cent increase over last year.

A net decline in spending for national defense since fiscal 1968, coupled with rapid expansion of other budget outlays, has resulted in a sharp decrease in the portion of the budget devoted to the military.

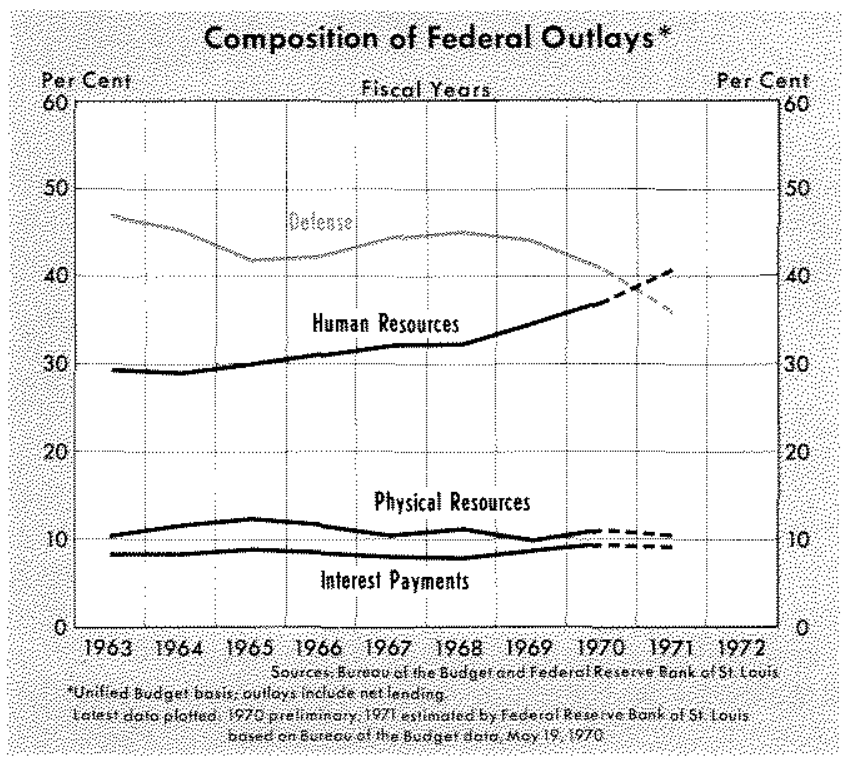

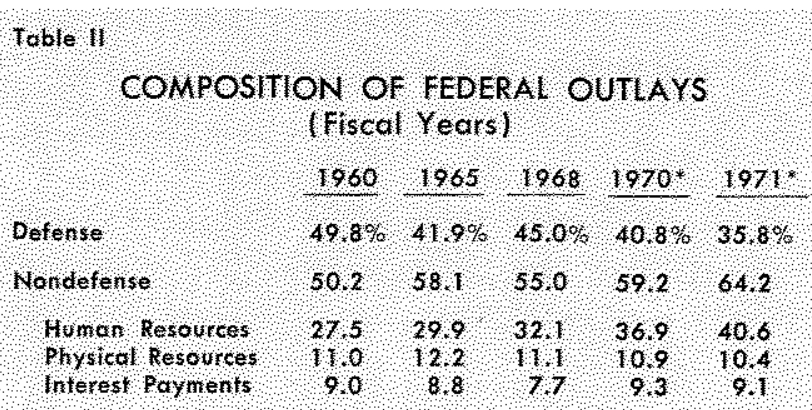

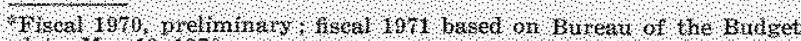
$\mathrm{atata} \mathrm{Ma} 10,1070$

Defense spending, as currently projected, would account for 36 per cent of the budget in fiscal 1971. During the period of military buildup in Vietnam, defense spending increased at at 17.5 per" cent average annual rate, from $\$ 49.6$ billion in fiscal 1965 to $\$ 80.5$ billion in fiscal 1968. This rapid rate of growth was almost matched, however, by expansion of nondefense spending. As a result the military's share of the budget did not change substantially, increasing from 42 per cent of total outlays in 1965 to 45 per cent in 1968.

Nondefense spending increased at an 11 per cent average rate from fiscal 1965 to 1970 and would account for 64 per cent of all outlays in fiscal 1971 . Programs devoted to human resources have shown the greatest expansion in recent years and, as currently projected, would account for almost 41 per cent of the budget in fiscal 1971, significantly greater than the 32 per cent allocated in fiscal 1968. Almost all of this increased share represents growth of spend. ing for Social Security and health programs. Other nondefense outlays would be increased 11 per cent in fiscal 1971 and be essentially unchanged as a proportion of total outlays. Physical resource projects, which include housing, urban development and transportation programs, would represent about 10 per cent of budget outlays in fiscal 1971, a share which has not changed substantially since 1960 .

In fiscal 1970 about 21 per cent of total spending (GNP) in the economy reflected some form of Federal spending, either directly, through Government purchases of goods and services, or indirectly, through transfers of income to the private sector. The proposed 4.5 per cent increase in budget outlays in fiscal 1971 implies that this relationship probably would not change significantly this year, but would be somewhat larger than in fiscal 1960 when the ratio was about 19 per cent. 


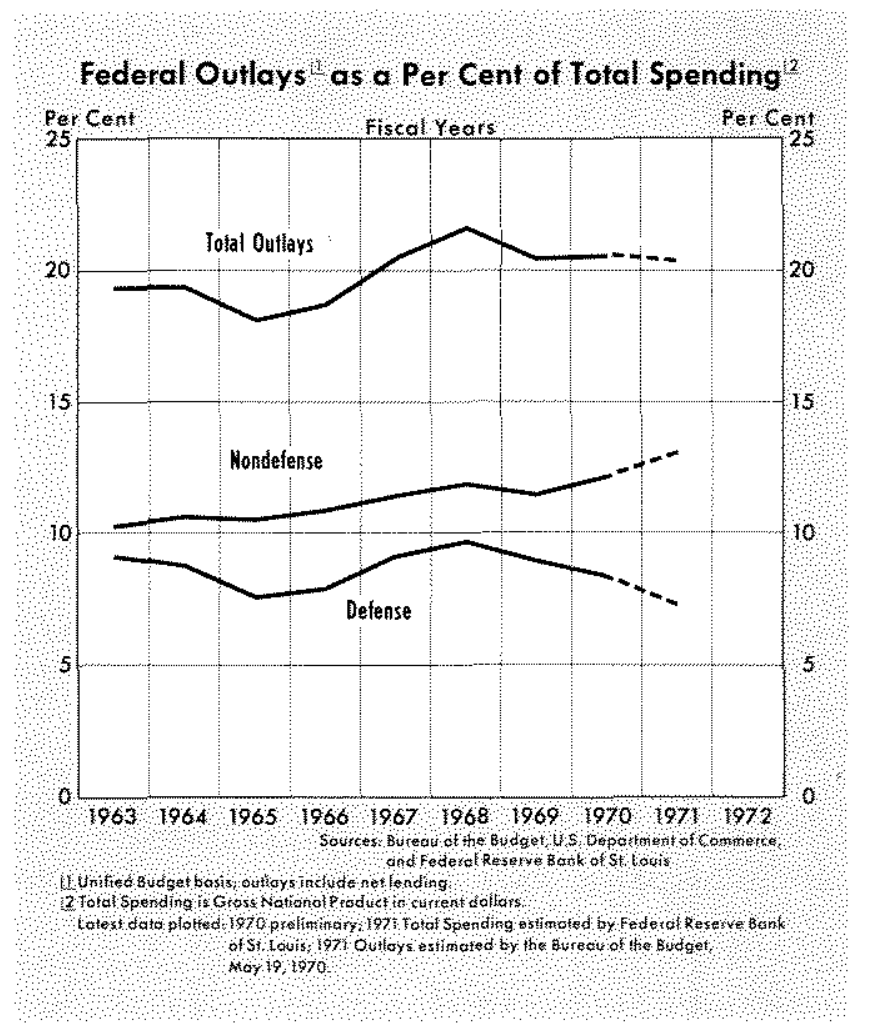

The relationship between Government outlays and total spending in the economy increased substantially from 1965 to 1968 , rising from 18 to about 22 per cent. During that period Government outlays for defense increased from 7.6 per cent to 9.7 per cent of total spending. The decline in defense outlays since 1968 has resulted in a sharp reduction in the portion of total spending associated with national security programs, and defense-related spending accounted for 8.4 per cent of total spending in fiscal 1970 . This share promises to decline further this year. Government spending for nondefense purposes has generally increased faster than total spending in the economy since 1960. From fiscal 1960 to fiscal 1970 the ratio of nondefense outlays to total spending rose from 9.3 per cent to 12.2 per cent. This proportion is expected to increase further in fiscal 1971.

While budget data for state and local governments are not directly comparable with the Federal budget used here, it is possible to make some approximate comparisons. ${ }^{1}$ State and local expenditures have ap parently increased slightly faster than total spending since fiscal 1960. As a per cent of total spending,

Budget data for state and local government forming a consistent series over time are available only on a National In. come Accounts basis.

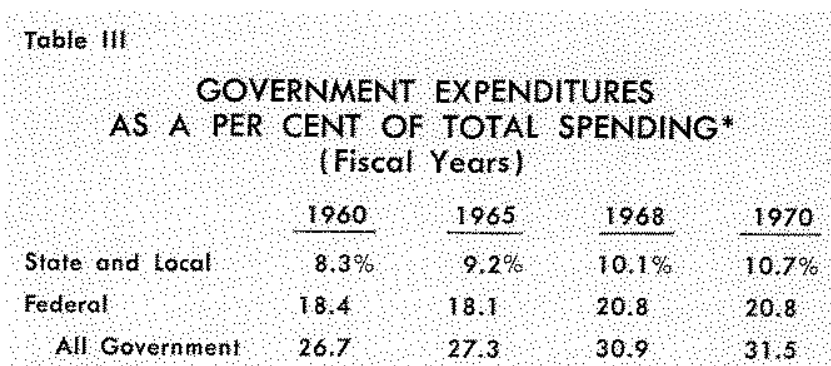

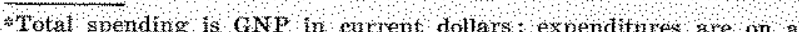

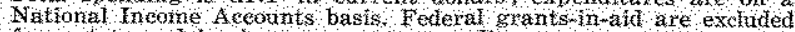
from state and lodal government expenditures

state and local expenditures increased from 8.3 per cent in fiscal 1960 to 10.7 per cent in fiscal 1970. This suggests that the portion of total spending in the economy which reflects some form of government expenditures has generally increased in the past decade, and probably accounts for approximately 30 per cent of spending.

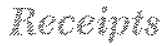

Taxable income tends to rise and fall with the pace of economic activity, and consequently the Federal budget tends toward deficit in periods of moderated growth of total spending. In the absence of new revenue legislation, total budget receipts in fiscal 1971 are expected to be approximately $\$ 3$ billion higher than in the previous year. This is a relatively slow increase and is due to the combined effects of an expected moderate rate of increase in economic activity, and the tax changes incorporated in the Tax Reform Act of 1969, including termination of the income tax surcharge on June 30, 1970. The tax reform provisions and elimination of the surcharge are expected to cost the Government about $\$ 3$ billion in revenue in fiscal 1971. In order to bolster revenue the Administration has proposed several new programs: a tax on leaded gasoline ( $\$ 1.6$ billion), a postal rate hike ( $\$ 1.5$ billion), and speeded collection of gift and estate taxes (\$1.5 billion). With adoption of these proposals, receipts in fiscal 1971 are estimated to be about $\$ 8$ billion higher than last year.

\section{mo noly}

The Federal budget for fiscal 1971 , as reviewed in May, was projected to show a deficit of $\$ 1.3$ billion. This was based, however, on an estimated deficit of $\$ 1.8$ billion in fiscal 1970 , an estimate which has since proved to be too low. The actual budget was in deficit by $\$ 2.9$ billion in fiscal 1970 . In January of this year the Administration had projected a budget sur- 
plus of $\$ 1.5$ billion for fiscal 1970 . This estimate was revised in May to a deficit of $\$ 1.8$ billion, with almost all of the change due to a shortfall in estimated receipts from the corporate profits tax. However, actual corporate and individual income tax receipts fell short of expectations, and total budget receipts in fiscal 1970 amounted to $\$ 193.8$ billion, compared with the May estimate of $\$ 196.4$ billion.

The Administration has not yet revised its budget projections for 1971 in light of the actual 1970 budget; however, there is now little prospect that the deficit of $\$ 1.3$ billion projected in May is realistic. For example, the Administration projected in May that revenue would increase by $\$ 7.9$ billion over fiscal 1970. Since actual revenue in 1970 was $\$ 2.6$ billion less than estimated in May, fiscal 1971 receipts would tend to be lower by the same amount. This implies that the Administration's proposed budget would be in deficit by at least $\$ 4$ billion this fiscal year. The budget deficit would be significantly larger than $\$ 4$ billion if Congressional actions result in expenditures beyond those requested by the Administration or if Congress is not receptive to the proposed new revenue programs.

\section{Impact on the Economy}

Table IV summarizes the pattern of economic activity which has been observed since the Government enacted restrictive, anti-inflationary fiscal policy in mid-1968. Inflation has accelerated, production growth has slowed and has been negative since last fall, and unemployment has increased. Interest rates, which many analysts expected to fall, have remained high.

This pattern of activity has led to suggestions that Government actions have had little effect on inflation and stimulative actions (both fiscal and monetary)

\section{Table IV}

\section{THE PATTERN OF ECONOMIC ACTIVITY} (Half-year Averages)

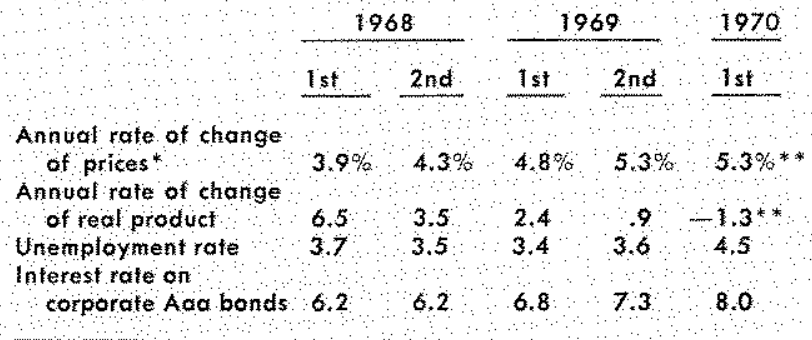

* GNP price defator

* Treliminazy are now required in order to bolster real economic activity. However, the Administration wants a budget close to balance in order to pursue the fight against inflation. In the May 19, 1970 revision of its February proposal, the Bureau of the Budget stated:

If the Congress votes higher appropriations, or does not approve the taxes proposed by the President, it should match these with specific cuts in other spending programs or increases in other taxes.

Continued fiscul restraint is essential to further progress toward the objectives stated in the President's budget message, Relaxation of that restraint now would risk the danger of permitting the econony to climb too fast as it begins to pick up in the months ahead. Too rapid an advance could nullify the progress made to date toward bringing inflation under control....

Since there is a growing belief that the budget deficit actually will be substantially larger than the President requested, it is important to analyze the probable impact of a large deficit on the economy.

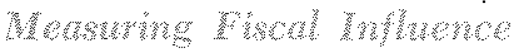

The high-employment budget, an often-used measure of fiscal influence, indicates that the budget for fiscal 1971, as proposed by the Administration, would be restrictive in its impact on economic activity. The high-employment measure of the budget eliminates most of the effects of changes in real economic activity on the budget and attempts to measure changes in the budget due solely to legislative action. Thus the growth of the tax base is held at its high-employment rate and the effects of varia-

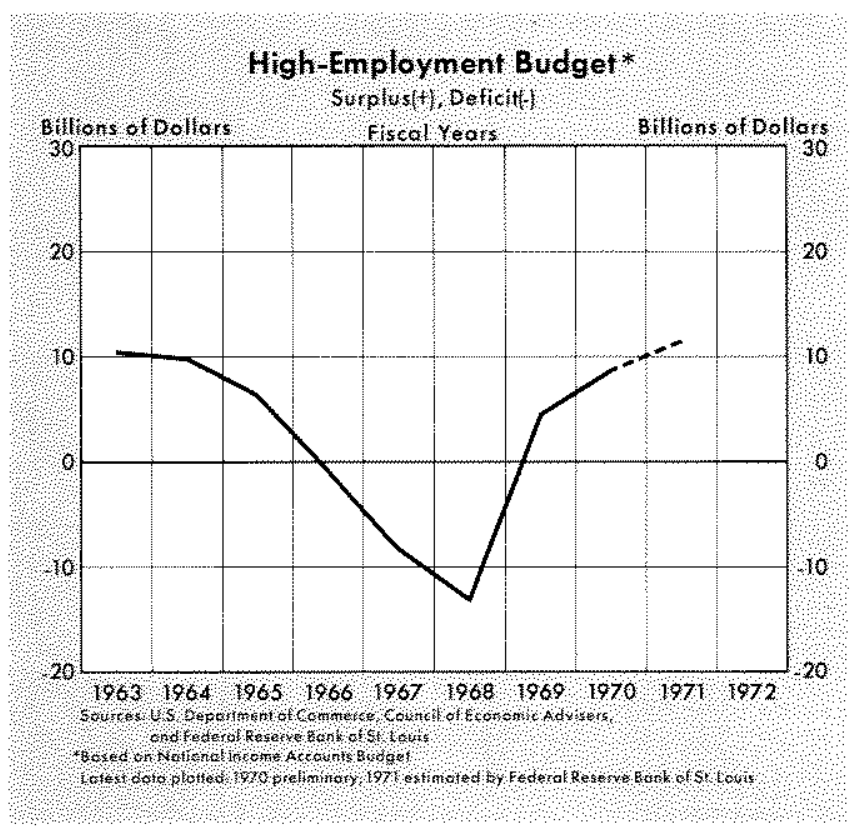


tion in economic activity on the budget are significantly reduced. If the budget is enacted as proposed, the high-employment budget would be in surplus by about $\$ 12$ billion in fiscal 1971 , about $\$ 3$ billion larger than in fiscal 1970. If the proposed revenue programs are not adopted or spending exceeds the projected level, the change in the high-employment surplus would be much smaller and the influence of fiscal actions woukd be less restrictive.

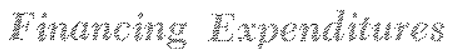

A key element which must be considered in analyzing the impact of the budget on the economy is the method the Govermment uses to finance its expenditures. The Government has three financing altematives: taxing, borrowing from the public sector, or borrowing from the Federal Reserve, which is the same as creating money. The effect of Government spending on economic activity can vary depending on the type of financing employed.

The amount of borrowing the Government will do in fiscal 1971 will be determined by the outlay and revenue programs adopted by Congress. From whom the Government borrows will determine the impact of the budget on the economy. Borrowing from the public, that is competing with individuals and businesses for credit funds, would tend to put upward pressure on interest rates. There would be little net increase in total spending in that the Government spending would supplant private spending programs that were unable to get credit.

If the Federal Reserve chose to alleviate some of this pressure on credit markets, however, the impact of Government borrowing would tend to be different. Monetary actions directed at increasing bank reserves and thus the supply of credit, could ease the immediate upward pressure on interest rates and contribute to a smaller restrictive effect on private borrowing. The Government essentially would be financing the deficit by money creation, and unlike taxing or borrowing from the public, money creation involves no crowding-out of private spending. ${ }^{2}$ Thus, Government borrowing in conjunction with accommodative monetary action would tend to have a more stimulative effect on total spending.

The budget deficits of the $1965-68$ period are gen-

\footnotetext{
SSeveral studies, in this Review and elsewhere, have con" cluded that Government expenditures not accompanied by money creation have only a temporary effect on total spending. Over a longer period of time such spending is believed simply to crowd out private spending.
}

erally believed to have been a major source of the current inflation. These deficits were due primarily to accelerated growth of Federal spending and since the economy was essentially fully employed in 1965 , the expansion of Government spending resulted in strong competition with the private sector for the output of the economy.

The Government chose not to increase taxes and thereby reduce private demand and release resources for Govermment use. Instead, the Government sought to borrow funds to finance its spending programs and had to compete for credit with the private sector. The expanded demand for credit put strong upward pressure on interest rates. Early in 1967, the Federal Reserve began to increase the money supply at a rapid rate and from January 1967 to January 1969, the nation's money stock increased at an average rate of 7.3 per cent. This growth of money was excessively rapid and contributed to an acceleration of total spending in the economy.

Price increases were generated by excessive demand as the Government competed with the private sector for the output of the economy. After rising at a 1.4 per cent average annual rate from 1960 to mid1965 , prices increased at an average rate of 3.2 per cent from mid-1965 to mid-1968. After-tax income of individuals rose at an accelerated 8.2 per cent average annual rate from mid-1965 to mid-1968, compared with a 6.4 per cent rate in the previous five years. However, constmer purchasing power (aftertax income adjusted for price increases) increased at a 4.8 per cent rate from mid-1965 to mid-1968, unchanged from a 4.9 per cent rate of increase in the earlier period.

\section{Bunchosen}

The Federal budget prospects are not now so ominous as they were three years ago in terms of immediately contributing to excessive total demand. The most expansionary type of budget deficit, one accompanied by $\mathrm{rapid}$ monetary growth, would surely stimulate total spending in the coming year but would probably have less of an effect on prices than in the $1965-68$ period. The acceleration of Gov emment spending in 1965 and the rapid rate of monetary expansion from early 1967 to late in 1968 contributed to growth of total spending far in excess of productive capacity, and prices increased sharply. Currently, however, production in the economy is significantly below potential and could be expanded somewhat in response to an increase in total spending. With some idle capacity in the economy, an increase 


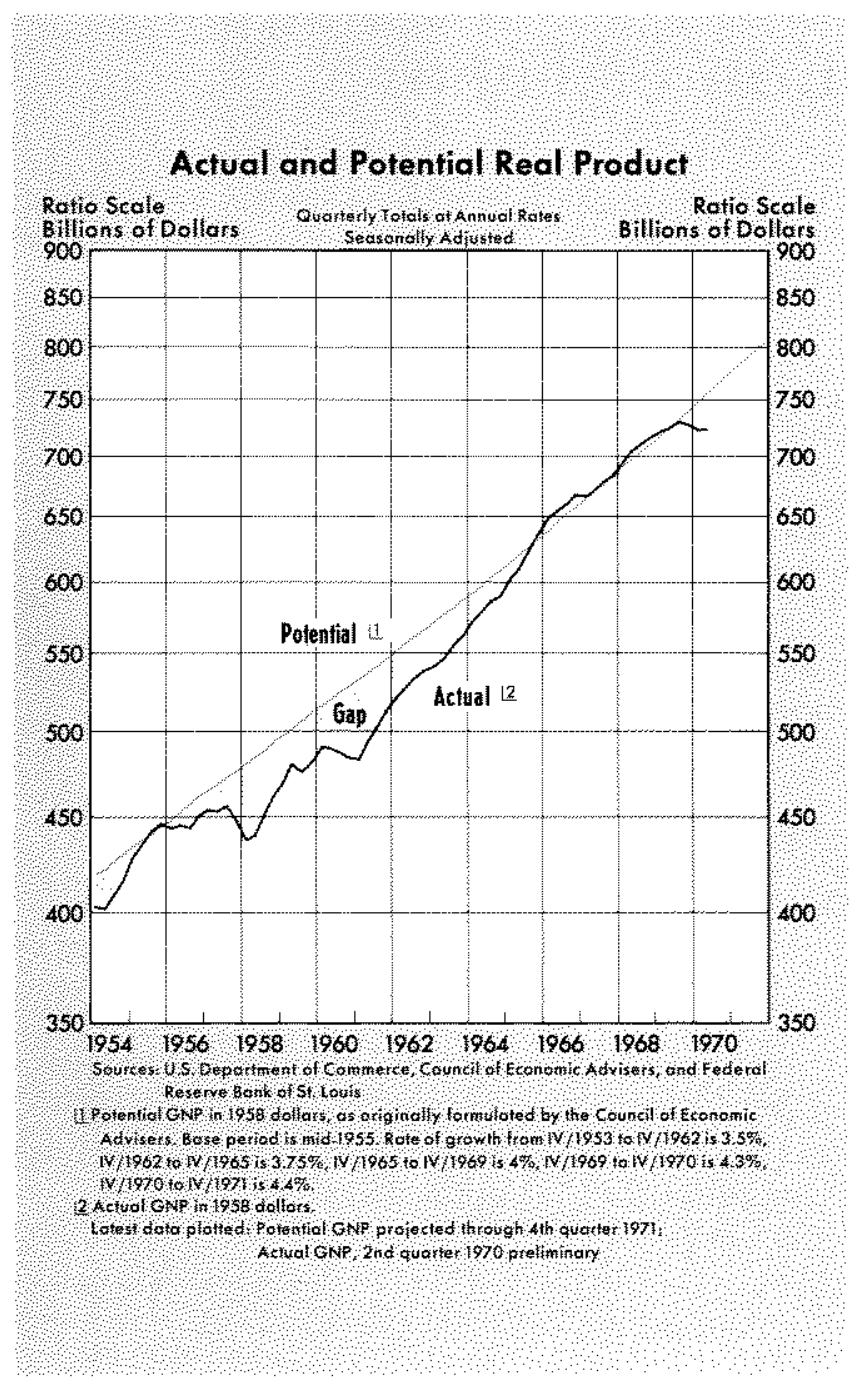

in total spending would tend to bolster production and employment in the coming year.

A resurgence of spending, however, could strongly affect the degree of downward adjustment in costpush factors two and three years from now. For example, rapid increases in total spending would alleviate some of the pressure on corporate profits and remove some of the incentives for cost-cutting programs currently underway. Increased production might also decrease some of the employment uncertainty in the labor force and contribute to strengthening of wage and salary demands. Thus while a large budget deficit may appear to be an attractive means of alleviating some of the current employment and production pains, the relief could be very expensive if it caused rapid inflation to last longer than necessary, or to actually accelerate in later years.

The budget as proposed by the Administration would have little, if any, effect on total spending in the coming year. There is a possibility that the deficit would be somewhat larger than the Administration estimated in May, but the larger deficit would be due to a shortfall of tax revenue, reffecting a moderate pace of total spending through this winter. In contrast, the deficits of the 1965-68 period were due to rapid expansion of Government spending at a time when the economy was essentially at full employment. Also a $\$ 4$ or $\$ 5$ billion deficit would not contribute to a rapid expansion of the money stock. If adopted, it would be a budget consistent with easing inflationary pressures over the next few years. 